\title{
The Utilization of Rum Slops by Marine Bacteria. II. Characterization of Efficient Strains ${ }^{1}$
}

\author{
D. R. Hale and T. R. Tosteson ${ }^{2}$
}

\begin{abstract}
Twenty bacterial isolates from selected marine communities were obtained employing solid, modified sea water media containing slops. Thirteen basic morphological, cytological, physiological and biochemical tests were conducled to characterize six of the strains that grew most successfully on the slops media.

The ability to hydrolyze high molecular weight sugars and proteins appears to be a necessary condition for the successful growth of some of these isolates on slops media. Tentative identifications of these bacterial strains were made.
\end{abstract}

\section{INTRODUCTION}

The growth in slops media of 20 bacterial isolates was studied. The bacterial strains that were able to grow (after approximately $24 \mathrm{~h}$ ) at what turned out to be the highest tolerable concentration of slops (4.04 $\mathrm{mg} / \mathrm{ml}$ ) were characterized morphologically, cytologically, physiologically, and biochemically. The different properties of the strains were compared and the probable roles of each strain in the degradation of slops are discussed. Tentative generic assignments are made where possible.

\section{MATERIALS AND METHODS}

The growth studies were conducted in the manner previously reported (7). The tests employed for the identification and characterization of the bacteria were based on established procedures $(2,3,4,5,6)$. Bergey's Manual (1) was employed to make tentative generic assignments.

\section{RESULTS AND DISCUSSION}

\section{GROWTH OF THE BACTERIA ON SLOPS}

The results of the growth studies conducted with strains DIALMUD 1 and DIALMUD 2 are presented in table 1. It can be seen that strain DIALMUD 1 was able to grow at a slops concentration of $4.04 \mathrm{mg} / \mathrm{ml}$, though it was able to do so only after at least $5 \mathrm{~h}$ of incubation. The substrate utilization efficiency (SUE), which is essentially the degree of growth of the bacterial strain during a given period of incubation divided by the concentration of slops employed (7) also occurred at a slops concentration of $4.04 \mathrm{mg} / \mathrm{ml}$ in this bacterial strain. Strain DIALMUD 1

\footnotetext{
${ }^{1}$ Manuscript submitted to Editorial Board May 22, 1978.

${ }^{2}$ Graduate Student and Professor respectively, Department of Marine Sciences, Mayagüez Campus, University of Puerto Rico, Mayagüez, P.R.
} 
TABLE 1.-Growth of two bacterial isolates in slops

\begin{tabular}{|c|c|c|c|c|c|c|}
\hline \multirow{2}{*}{ Determination } & \multicolumn{6}{|c|}{ Crude slops concentration $(\mathrm{mg} / \mathrm{ml})$} \\
\hline & 0.00 & 0.404 & 0.808 & 1.62 & 4.04 & 6.06 \\
\hline \multicolumn{7}{|c|}{ Dialmud 1} \\
\hline OD $(5 \mathrm{~h})$ & -0.042 & +0.404 & +0.138 & +0.323 & +0.03 & -0.02 \\
\hline $\mathrm{OD}(24 \mathrm{~h})$ & -0.029 & +0.048 & +0.118 & +0.393 & +1.3 & +0.07 \\
\hline SUE $^{1}$ & & & 0.147 & 0.243 & 0.322 & \\
\hline \multicolumn{7}{|c|}{ Dialmud 2} \\
\hline OD $(5 \mathrm{~h})$ & -0.26 & & +0.213 & +0.349 & +0.015 & \\
\hline OD $(24 \mathrm{~h})$ & -0.030 & & +0.373 & +0.654 & +0.03 & \\
\hline SUE $^{\prime}$ & & & 0.338 & 0.404 & & \\
\hline
\end{tabular}

'Based on the $24 \mathrm{~h}$ incubation.

was thus able to overcome the inhibitors present in slops. These data suggest that the bacteria were initially at a steady state in the culture and that they were able to detoxify the medium by either slowly metabolizing the inhibitors and/or inactivating them by the secretion of appropriate extracellular materials. The optimum growth and SUE of strain DIALMUD 2 occurred at the $1.62 \mathrm{mg} / \mathrm{ml}$ concentration of slops (table 1).

The 10 isolated strains of bacteria whose growth was characterized by cellular aggregation and "clump" formation (CRRT 1, CRRT 4, CRMRS 1, CRMRS 3, CRSED 1, DIALRT 1, DIALMRS 1, DIALMRS 2, DIALSED 1 and CRMUD 3) were grown at a slops concentration of 4.04 $\mathrm{mg} / \mathrm{ml}$ for periods of $24 \mathrm{~h}$. Only one of these strains, CRMRS 3, showed any ability to grow at this concentration of the slops. Thus, of the 20 bacterial strains that were able to grow in the slops agar employed in their initial isolation, approximately one-fourth of these were able to grow at slops concentrations as high as $4.04 \mathrm{mg} / \mathrm{ml}$.

\section{CHARACTERIZATION OF THE MARINE BACTERIAL ISOLATES THAT EXHIBITED THE BEST GROWTH IN THE SLOPS}

Thirteen basic morphological, cytological, physiological and biochemical tests were conducted with each strain of bacteria in order for the researchers to get some idea of the taxonomical and physiological types of marine bacteria that degrade the slops. The strains examined were CRRT 2, DIALMR 1, CRMUD 2, DIALMUD 1, and CRMRS 3. DIALMUD 1 was found to be impure upon careful examination and was separated into two strains of bacteria designated as DIALMUD $1 \mathrm{~W}$ and DIALMUD $1 \mathrm{C}$.

The test results are presented in table 2. All of the strains were of the gram negative, aerobic or facultatively anaerobic, short rod type of bacteria. None of the six strains tested appeared to be duplicates. DIAL- 
MUD $1 \mathrm{~W}$ and CRMRS 3 produce pigment when grown on nutrient agar, though they did not appear to do so on the slops agar. Four of the six bacterial strains examined were strict aerobes, the other two being facultative anaerobes.

The two facultative anaerobes (DIALMR 1 and CRMUD 2) showed powerful diastatic as well as proteolytic activity in nutrient gelatin and litmus milk. The aerobe CRMRS 3 grew slowly in nutrient gelatin and litmus milk, but did show proteolytic activity in each. It would be expected that bacteria with such abilities would be likely to degrade polysaccharide or proteinaceous materials found in spent fermentation wastes such as the slops. In addition, DIALMUD 1 C hydrolyzed gelatin readily, but did not attack starch or milk.

CRRT 2 and DIALMUD $1 \mathrm{~W}$ did not attack starch, gelatin or milk, however, appeared to grow well on the slops at a concentration of 4.04 $\mathrm{mg} / \mathrm{ml}$. Thus the ability to hydrolyze high molecular weight sugars and proteins appeared not to be a necessary condition for the growth of this marine bacterium on the crude slops. Probably the most significant factor controlling the initial proliferation of marine bacteria in a sea water-slops medium is the tolerance of the particular strain to the inhibitors present.

Longer term incubations would likely provide these bacteria with ample time to detoxify the slops and thus be able to degrade it more fully. Evidence presented previously in this report suggests that such a detoxification process does take place. Proper manipulation of such reasonably "resistant" bacteria, especially the ones that have the ability to degrade the polysaccharide and proteinaceous substances, might provide an efficient system for the digestion of the slops. However, the data suggest that this would have to be done at relatively dilute slops concentration over a period exceeding $24 \mathrm{~h}$. The potential harvestable "bacterial protein" could conceivably make such a process commercially viable.

TENTATIVE IDENTIFICATION OF THE SIX BEST-GROWING BACTERIAL STRAINS

Based on the tests performed, tentative identifications of the bacterial strains were attempted. The following tabulation summarizes these results:

Bacterial Strain

Genera

\begin{tabular}{lll} 
CRRT 2 & Likely & \multicolumn{1}{c}{$\begin{array}{c}\text { Possible } \\
\text { Pseudomonas } \\
\text { Alcaligenes }\end{array}$} \\
Pseudomonas \\
ALMD 1 W & & \\
CRMRS 3 & Pseudomonas & Pseudomonas \\
ALMR 1 & & Aeromonas \\
AMUD 2 & Vibrio & Aeromonas
\end{tabular}


TABLE 2.-Characterization of the marine bacterial isolates

\begin{tabular}{|c|c|c|c|c|c|c|}
\hline \multirow{4}{*}{$\begin{array}{l}\text { Test } \\
\text { Cell morphology } \\
\text { (unstained, oil } \\
\text { immersion } \\
\text { phase) }\end{array}$} & \multicolumn{6}{|c|}{ Bacterial strain } \\
\hline & CRRT 2 & DIALMUD $1 \mathrm{~W}$ & DIALMUD $1 \mathrm{C}$ & CRMRS 3 & DIALMR 1 & CRMUD 2 \\
\hline & (1) (w) & (1) $\quad(w)$ & (1) $\quad(w)$ & (1) (w) & $(w)$ & $(w)$ \\
\hline & $\begin{array}{c}\text { Rods } 1.6-3.2 \times \\
0.8-1.2(\mu \mathrm{m})\end{array}$ & $\begin{array}{l}\text { Rods } 0.8-1.6 \times 0.4 \\
\quad(\mu \mathrm{m})\end{array}$ & $\begin{array}{l}\text { Rods } 1.6-2.4 \times 0.8 \\
\quad(\mu \mathrm{m})\end{array}$ & $\begin{array}{l}\text { Curved rods } \\
2.4-4.0 \times 1-1.5 \\
(\mu \mathrm{m})\end{array}$ & $\begin{array}{l}\text { Rods } 1.6-2.4 \times 0.8 \\
\quad(\mu \mathrm{m})\end{array}$ & $\begin{array}{l}\text { Rods } 1.6-2.4 \times 0.8 \\
\qquad(\mu \mathrm{m})\end{array}$ \\
\hline Gram reaction & Negative & Negative & Negătive & Negative & Negative & Negative \\
\hline $\begin{array}{l}\text { Motility (hanging } \\
\text { drop) }\end{array}$ & Sluggishly motile & Motile & Motile & Non-motile & Very motile & Very motile \\
\hline $\begin{array}{l}\text { Temperature of } \\
\text { incubation }\end{array}$ & $22-24^{\circ} \mathrm{C}$ & $22-24^{\circ} \mathrm{C}$ & $22-24^{\circ} \mathrm{C}$ & $22-24^{\circ} \mathrm{C}$ & $22-24^{\circ} \mathrm{C}$ & $22-24^{\circ} \mathrm{C}$ \\
\hline Starch hydrolysis & Negative & Negative & Negative & Negative & Positive & Positive \\
\hline Gelatin hydrolysis & Negative & Negative & Positive & $\begin{array}{l}\text { Positive (slow, but } \\
\text { complete) }\end{array}$ & Positive & Positive \\
\hline \multicolumn{7}{|l|}{$\begin{array}{l}\text { Carbohydrate fer- } \\
\text { mentations }\end{array}$} \\
\hline glucose & 0 & A & 0 & A & 0 & A \\
\hline sucrose & 0 & 0 & 0 & 0 & 0 & A \\
\hline lactose & 0 & 0 & 0 & 0 & 0 & 0 \\
\hline $\begin{array}{l}\text { Litmus milk reac- } \\
\text { tion }(3 \% \mathrm{NaCl})\end{array}$ & $\begin{array}{l}\text { Reduction of lit- } \\
\text { mus; no curd } \\
\text { formation, no } \\
\text { proteolysis }\end{array}$ & $\begin{array}{l}\text { Reduction of lit- } \\
\text { mus; to red } \\
\text { (surface), no } \\
\text { curds, no prote- } \\
\text { olysis after } 1.5 \\
\text { weeks }\end{array}$ & $\begin{array}{l}\text { Slow reduction of } \\
\text { litmus, no } \\
\text { curds, no prote- } \\
\text { olysis }\end{array}$ & $\begin{array}{l}\text { Reduction of lit- } \\
\text { mus, "sweet" } \\
\text { curds, proteoly- } \\
\text { sis in progress, } \\
\text { transparent } \\
\text { layer becomes } \\
\text { blue }\end{array}$ & $\begin{array}{l}\text { Reduction of lit- } \\
\text { mus (reversi- } \\
\text { ble); top layer } \\
\text { blue; proteoly- } \\
\text { sis in progress } \\
\text { (increasing } \\
\text { transparency) }\end{array}$ & $\begin{array}{l}\text { Litmus reduced, } \\
\text { proteolysis in } \\
\text { progress }\end{array}$ \\
\hline $\begin{array}{l}\text { Oxygen require- } \\
\text { ment }\end{array}$ & $\begin{array}{c}\text { Aerobe (surface } \\
\text { growth only) }\end{array}$ & $\begin{array}{c}\text { Aerobe (surface } \\
\text { growth only) }\end{array}$ & $\begin{array}{l}\text { Aerobe (surface } \\
\text { growth only) }\end{array}$ & $\begin{array}{l}\text { Aerobe (surface } \\
\text { growth only) }\end{array}$ & $\begin{array}{l}\text { Fac. anaerobes; } \\
\text { growth } \\
\text { throughout, mi- } \\
\text { croaerophilic } \\
\text { band }\end{array}$ & $\begin{array}{c}\text { Facultative anaer- } \\
\text { obe (growth } \\
\text { throughout) }\end{array}$ \\
\hline
\end{tabular}




\begin{tabular}{|c|c|c|c|c|c|c|}
\hline \multicolumn{7}{|c|}{ Growth in nutrient broth $(0.3 \%$ beef extract, $0.5 \%$ peptone $)$} \\
\hline membrane & Yes & Yes (peeling) & Slight & Slight & Yes & Yes \\
\hline pellicle & No & No & No & No & No & No \\
\hline ring & Slight & No & No & Yes & No & No \\
\hline sediment & Yes & Slight & Slight & Yes & Yes & Slight \\
\hline comments & $\begin{array}{l}\text { Growth spread } \\
\text { surface bottom } \\
\text { over } 48 \mathrm{hrs}\end{array}$ & $\begin{array}{l}\text { Growth through- } \\
\text { out }\end{array}$ & $\begin{array}{l}\text { Growth through- } \\
\text { out ( } 48 \mathrm{hrs)} \text {, } \\
\text { small flocs }\end{array}$ & $\begin{array}{l}\text { Growth through- } \\
\text { out }\end{array}$ & $\begin{array}{l}\text { Growth through- } \\
\text { out (24 hours) }\end{array}$ & $\begin{array}{l}\text { Growth through- } \\
\text { out }\end{array}$ \\
\hline Agar slope & Filiform & Filiform & Filiform & Filiform & $\begin{array}{l}\text { Filiform-arbores- } \\
\text { cent }\end{array}$ & Effuse \\
\hline Catalase test & Strong positive & Positive & Positive & Positive & Positive & Negative \\
\hline \multicolumn{7}{|c|}{ Colony morphology $(0.3 \%$ beef extract, $0.5 \%$ peptone, $1.5 \%$ agar $)$} \\
\hline color & Off-white & Light orange & White & Yellow & Off-white & Off-white \\
\hline shape & Circular & $\begin{array}{l}\text { Punctiform-circu- } \\
\text { lar }\end{array}$ & Circular & Circular & Irregular & $\begin{array}{l}\text { Irregular, colonies } \\
\text { not formed }\end{array}$ \\
\hline elevation & Convex & Convex & Convex & Convex & Convex & Convex \\
\hline edge & Entire & Entire & Entire & Entire & Entire & Entire-undulate \\
\hline surface & $\begin{array}{l}\text { Smooth, glisten- } \\
\text { ing }\end{array}$ & $\begin{array}{l}\text { Smooth, glisten- } \\
\text { ing }\end{array}$ & $\begin{array}{l}\text { Smooth, glisten- } \\
\text { ing }\end{array}$ & $\begin{array}{l}\text { Smooth, glisten- } \\
\text { ing }\end{array}$ & $\begin{array}{l}\text { Smooth, glisten- } \\
\text { ing }\end{array}$ & $\begin{array}{l}\text { Smooth, glisten- } \\
\text { ing }\end{array}$ \\
\hline optical & Mildly opaque & Opaque & Mildly opaque & $\begin{array}{l}\text { Opaque, clear } \\
\text { area around }\end{array}$ & $\begin{array}{c}\text { Reasonably } \\
\text { opaque }\end{array}$ & Opaque \\
\hline
\end{tabular}

' Natural seawater was used as the base in all of the culture media except that of the litmus milk. Fermentations were done with Durham tubes in Trypticase-Yeast Extract based media. 


\section{RESUMEN}

Veinte cepas bacterianas de comunidades marinas seleccionadas se aislaron en un medio de cultivo sólido modificado que contenía agua de mar y mosto.

Trece pruebas morfológicas, citológicas, fisiológicas y bioquímicas se realizaron para caracterizar seis de las cepas que crecieron mejor en el medio de cultivo con mosto.

Estas cepas bacterianas han sido identificadas tentativamente.

\section{LITERATURE CITED}

1. Buchanan, R. E. and Gibbons, N. E., Ed. 1974. Bergey's Manual of Determinative Bacteriology, 8th ed, The Williams and Wilkins Co., Baltimore.

2. Brock, T. D., 1974. Biology of Micro-organisms, 2nd ed, Prentice-Hall, Inc., Englewood Cliffs, New Jersey.

3. Collins, C. H. and Lyne, P. M., Ed. 1970. Microbiological Methods, 3rd ed, University Park Press, Baltimore.

4. Manual of the Methods for Pure Culture Study of Bacteria, 1955. Edited by the Committee on Bacteriological Technic of the Society of American Bacteriologists. Biotech. Publ., Geneva, New York.

5. Pelczar, M. J., Jr., 1965. Laboratory Exercises in Microbiology, 2nd ed, McGraw-Hill Book Company, New York.

6. Seeley, H. W., Van Demark, P. J., 1972. Microbes in Action, A Laboratory Manual of Microbiology, 2nd ed, Freeman, W.H. and Co., San Francisco.

7. Tosteson, T. R. and Hale, D. R., The utilization of slops by marine bacteria. I. Isolation of efficient strains, RPP-11, April 1978, Rum Pilot Plant, Agri. Exp. Stn., Univ. P.R., Río Piedras, P.R. 